\title{
AOR
}

Selected Papers of \#AoIR2020:

The $21^{\text {st }}$ Annual Conference of the

Association of Internet Researchers

Virtual Event / 27-31 October 2020

\section{THE POLITICS OF INTERNET FREEDOM RANKINGS: A CALL FOR A COMPARATIVE FRAMEWORK FOR ASSESSING INTERNET FREEDOM}

\author{
Mariëlle Wijermars \\ Maastricht University \\ Tetyana Lokot \\ Dublin City University
}

This paper critically assesses current regimes of internet governance and the role of internet freedom rankings therein. In particular, it aims to initiate a debate ultimately leading to the development of a groundbreaking comparative framework for assessing internet policy, departing from the assumption that current frameworks for assessing and measuring internet freedom are predicated too strictly on the dichotomy of democracy/non-democracy.

\section{Background and Context}

Existing scholarship on internet use and internet governance has drawn connections between the level of democratic development (or lack thereof) in countries and the level of internet freedom in them. On the one hand, scholars have argued that it is possible to design multi-level models that demonstrate the complex relationship between the level of democratisation, internet use and internet penetration (Nisbet, Stoycheff and Pearce, 2012), although there may be discrepancies between perceived and actual levels of internet freedom (Stoycheff 2020). On the other hand, opinion research involving internet users (Internet Society, 2012; Pew Research Center, 2014) suggests that demand for internet freedom is in itself a function of internet use and digital literacy. The type of online activities may also mediate the effect of internet use in authoritarian states, where recreational use was found to be "associated with satisfactory evaluations of non-democratic regimes and more entrenched authoritarian worldviews" (Stoycheff, Nisbet and Epstein, 2016). The implications of regime type influence on internet

Suggested Citation (APA): Wijermars, M., Lokot, T. (2020, October). The politics of internet freedom rankings: a call for a comparative framework for assessing internet freedom. Paper presented at AolR 2020: The $21^{\text {th }}$ Annual Conference of the Association of Internet Researchers. Virtual Event: AolR. Retrieved from http://spir.aoir.org. 
freedom have also, in many cases, been extrapolated from the relationship between press or media freedom and the level of democratic consolidation in a society. However, as Shen (2017) points out, internet freedom is a far more contested concept than press freedom due to the global reach of its policy implications. In particular, freedom of access, for example to facilitate the delivery of governmental services and distance education, is more widely recognized by states than the freedom of use - to express opinions, share and receive information online without bounds - that is often assumed under the notion of internet freedom measured by international rankings. Researchers such as DeNardis (2014) have also documented the emerging tensions between the globalisation of internet governance and the rising concern with internet sovereignty among nation-states that transcends regime types. At the same time, Farrell and Newman (forthcoming) argue that illiberal states are increasingly subverting the norms of global information openness to pursue their own interests, misaligned with the imaginary of the liberal international information order.

Furthermore, the development of internet governance principles and the benchmarking of indicators of internet freedom or internet control is an iterative process that involves multiple stakeholders, including civil society organisations, private sector initiatives, and governmental and intergovernmental organisations (Hawtin, 2011). Most of these actors approach the assessment of internet freedom from a Western-leaning perspective that uncritically assumes that democratic governance and democracy-related practices are embedded in the very origins of the internet (Morozov, 2011) and therefore, the levels of democratisation can serve as valid indicators of internet freedom as opposed to governance and practices in authoritarian states. As a result, these frameworks lack analytical capacity when applied to invasive internet policies and public administration practices implemented in democracies, while lacking analytical complexity when applied to policies and public administration practices in non-democracies. For example, they allow little room for acknowledging differences between the terms in which legal acts are stated and their implementation (impact on citizens in practice).

The conceptualization and operationalization of the concept of internet freedom that underlies internet freedom rankings is of particular importance since the promotion of internet freedom is an integral part of foreign policy of, e.g., the US and EU (e.g. the EU Action Plan for Human Rights and Democracy 2020-2024), and rankings serve as an important source of information and justification for prioritizing funding and efforts (Maréchal, 2015). Rankings are also known to impact states' reputations, serving as advocacy tools in public diplomacy, but also impeding justified criticism aimed at states who score well on key indicators.

\section{Call for Action and Rationale}

Through this intervention piece, we aim to initiate debate that will lead towards the development of an alternative framework for assessing internet policy that departs from the level of invasiveness into the private life of citizens and degree of governmental accountability and transparency, as well as the broader societal consequences of such policies and public administration practices. Shifting attention away from the singular focus on regime kind and politics enables us to develop a more complex system of coordinates for assessment. For example, a democracy can be found to have 
characteristics of an "authoritarian" legal framework regarding internet access, networked communications or data, or vice versa.

We begin by examining the existing frameworks and rankings of internet freedom to critically assess their parameters, indicators and analytical capacity. In our critical assessment we draw on emergent scholarship about regime hybridity and complexity, as well as research examining aspects of internet governance across regime types. On the basis of this analysis, we will propose initial ideas for conducting comprehensive regime-agnostic assessment of internet policies, governance practices and internet freedoms. Our aim is to develop a framework with both analytical capacity and complexity that can be used to critically evaluate internet governance regulations and practices across political systems and regime types.

\section{Contribution}

The paper makes a significant contribution to our understanding of internet freedom as distinct from political systems or media systems that inform much of the current research, policy and practice. Through its critical assessment of, e.g., the input variables used to calculate existing rankings (e.g., Freedom House Freedom on the Net or Index on Censorship) in line with the approach specified above, the intervention paper identifies key issues and shortcomings in existing approaches to evaluating internet policy, legislation and regulation, and therefore, the levels of internet freedom, that our alternative framework will seek to address. It serves as a first conceptual intervention in the interdisciplinary scholarly debate on regimes of internet governance and a stepping stone towards the operationalisation and testing of the comparative analysis framework.

\section{References}

DeNardis, L. (2014). The global war for internet governance. Yale University Press.

Farrell, Henry, and Abraham L. Newman. (forthcoming). The Janus Face of the Liberal International Information Order: When Global Institutions are Self-Undermining. International Organization.

Hawtin, D. (2011). Internet charters and principles: Trends and insights. Global Information Society Watch 2011, 49-54. Retrieved from http://giswatch.org/sites/default/files/gisw2011_en.pdf.

Internet Society. (2012). The global Internet user survey infographic. Reston, VA: Internet Society. Retrieved from http://www. Internetsociety.org/Internet/global-Internetuser-survey-2012.

Maréchal, N. (2015). COMPASS| Ranking Digital Rights: Human Rights, the Internet and the Fifth Estate. International Journal of Communication, 9, 10. 
Morozov, E. (2011). Whither Internet control? Journal of Democracy, 22(2), 62-74. doi:10.1353/jod.2011.0022

Nisbet, E. C., Stoycheff, E., \& Pearce, K. E. (2012). Internet use and democratic demands: A multinational, multilevel model of Internet use and citizen attitudes about democracy. Journal of Communication, 62(2), 249-265.

Pew Research Center. (2014). Emerging and developing nations want freedom on the Internet: Young especially opposed to censorship. Washington, DC: Pew Research Center. Retrieved from http://www.pewglobal.org/2014/03/19/emerging-and-developingnations-want-freedom-on-thelnternet/.

Shen, F. (2017). Internet use, freedom supply, and demand for internet freedom: A cross-national study of 20 countries. International journal of communication, 11, 22.

Stoycheff, E., E. Nisbet and D. Epstein (2016). Differential Effects of Capital-Enhancing and Recreational Internet Use on Citizens' Demand for Democracy. Communication Research. Published online first 25 April 2016.

Stoycheff, E. (2020) Relatively democratic: How perceived Internet interference shapes attitudes about democracy. International Journal of Press/Politics, 25(3), 390-406. 